\title{
Multi-dimensional evaluation and ranking of coastal areas using GIS and multiple criteria choice methods
}

\author{
Dimitra Kitsiou $^{\mathrm{a}, *}$, Harry Coccossis ${ }^{\mathrm{b}}$, Michael Karydis ${ }^{\mathrm{a}}$ \\ ${ }^{a}$ University of the Aegean, Department of Marine Sciences, 5 Sapfous Str., 81100 Mytilene, Greece \\ ${ }^{\mathrm{b}}$ University of the Aegean, Department of Environmental Studies, 17 Karadoni Str., 81100 Mytilene, Greece
}

Received 12 October 2000; accepted 10 March 2001

\begin{abstract}
Coastal ecosystems are increasingly threatened by short-sighted management policies that focus on human activities rather than the systems that sustain them. The early assessment of the impacts of human activities on the quality of the environment in coastal areas is important for decision-making, particularly in cases of environment/development conflicts, such as environmental degradation and saturation in tourist areas. In the present study, a methodology was developed for the multi-dimensional evaluation and ranking of coastal areas using a set of criteria and based on the combination of multiple criteria choice methods and Geographical Information Systems (GIS). The northeastern part of the island of Rhodes in the Aegean Sea, Greece was the case study area. A distinction in sub-areas was performed and they were ranked according to socio-economic and environmental parameters. The robustness of the proposed methodology was assessed using different configurations of the initial criteria and reapplication of the process. The advantages and disadvantages, as well as the usefulness of this methodology for comparing the status of coastal areas and evaluating their potential for further development based on various criteria, is further discussed. (c) 2002 Elsevier Science B.V. All rights reserved.
\end{abstract}

Keywords: Multi-dimensional evaluation; Multiple criteria choice methods; Geographical information systems (GIS); Coastal area; Marine eutrophication

\footnotetext{
* Corresponding author. Tel.: +30-251-36815; fax: +30-251-36809.

E-mail address: dkit@aegean.gr (D. Kitsiou).
} 


\section{Introduction}

The coastal zone contains diverse and unique resources as well as ecosystems that are important for biological and economic productivity, functioning also as an ecotone, a transition protective area between the land and the sea (Clark, 1983). Approximately $60 \%$ of the world's population lives within $60 \mathrm{~km}$ of the coast and this number is increasing rapidly due to the advantages it offers for a variety of human activities such as tourism, transport and fishing (Sorensen and McCreary, 1990). However, the coexistence of coastal ecosystems and human activities along the coastline inevitably results in competition for resources and environmental degradation with a negative impact on the economic and social value of the coast (Camhis and Coccossis, 1982). Tourism is a major industry worldwide and is expected to be the largest single economic activity in the 21st century. A large number of tourists are oriented to coastal areas seeking sun and sea, particularly in the Mediterranean (Lanquar, 1995), affecting the use of coastal resources and ecosystems directly and indirectly (e.g. loss of wetlands and dunes due to tourist development, coastal erosion, etc.). In that context, the waste generated from tourism is a major source of environmental pollution in many coastal communities (Madan and Rawat, 2000). The interesting case with pollution and tourism is the existence of strong feedback mechanisms affecting eventually tourism itself as an activity, since environmental quality is an important prerequisite for tourism attraction (Coccossis, 1996). Considering the marine coastal environment in particular, one of the related major environmental problems is eutrophication resulting from nutrient (nitrogen and phosphorus) inflow into the sea (Tivy and O'Hare, 1981; Gray, 1992) due to domestic sewage, as well as industrial or agricultural activities. The impact of agriculture activities on the coastal zone can occur both locally and remotely and can be extremely significant; agriculture is considered as the source of non-point source pollution and of the supply of nutrients to the sea coastal zone (Capobianco, 1999).

The strong interaction, therefore, between the human activities on the coastline and environmental quality has been the basis of seeking appropriate policies to ensure development opportunities and mitigate their impacts on the environment in the context of sustainable development. Moreover, this conflict between economic development and coastal environmental quality has led scientific research to seek appropriate methodologies for assessing environmental problems (Vollenweider, 1992) and the development of decision-support systems for evaluating the current state and predicting future trends in coastal areas (Kenchington, 1992; Ballinger and Smith, 1994). However, since coastal management requires the integration of environmental protection and development policies to ensure a rational use of coastal resources, the incompatibilities between ecological and social science perspectives and methodologies increase the complexity of developing appropriate coastal management tools (Belfiore, 2000). The technology that appears to be most likely to play a role in the development of Integrated Coastal Zone Management (ICZM) tools is Geographical Information Systems (GIS) (Capobianco, 1999); the integration of GIS with predictive models is extremely important in coastal management efforts worldwide (Jones, 1995). Moreover, based on the results of different research projects launched for assessing the appropriate mechanisms and procedures for an ICZM (EC, 1999; Doody et al., 1999); among others, a multi-attribute analysis is considered important (King, 1999). The purpose of this analysis was to provide a means for the aggregation of disparate information on environmental impacts into a single common measure and comprises the following four steps (King, 1999): structuring of the problem; development and application of a scoring or rating system to predicted impacts; application of a weighting system for indicating the importance of an impacted category compared to another; and aggregation of weighted scores into an overall measure of impact.

In the present work, an effort has been made to develop a methodology for the multi-dimensional evaluation and ranking of coastal areas based on both environmental and socio-eco- 
nomic criteria using a combination of multiple criteria choice methods and Geographical Information Systems (GIS). Geographical Information Systems have already been used for assessing environmental problems (Tsakiri-Strati et al., 1994; Golojuch, 1994), since they provide a powerful tool for the manipulation and analysis of spatial information (Carver, 1991; Goodchild et al., 1992; Barras et al., 1994; Carlson et al., 1994). The multiple criteria choice methods on the other hand have already been used to investigate a number of choice possibilities based on criteria derived from conflicting objectives (Voogd, 1983). Moreover, their additional advantage of considering simultaneously information expressed in both metric and non-metric form (Nijkamp and Voogd, 1986) has established them as an important tool in policy analysis, physical planning and environmental management (Hartog et al., 1989).

In the present study, the developed methodology acquired the simultaneous analysis of economic, social and ecological data collected from the coastal area under examination; a case study in the island of Rhodes, Greece was carried out. The study area was divided into three subareas/zones, since zoning is considered a valuable technique for guiding future policies (UNESCO, 1993); the aim was to explore the current status of these sub-areas and the potential for further development by maintaining the quality of the marine environment using different configurations of the set of criteria. The resulting ranking of the sub-areas based on the priority/weight given to each criterion allowed the assessment of the importance of each area compared to the others. As a final step, an attempt was made to evaluate the sensitivity of the developed methodology by condensing the information carried by the criteria. The importance of this methodology in the management of coastal areas is also discussed.

\section{Materials and methods}

\subsection{Data pre-processing}

The dataset used included socioeconomic and environmental parameters related to the sea environment and the neighboring mainland from the coastal area of the city of Rhodes, Greece. The parameters related to the marine environment were mean values of the concentrations of phosphate and nitrate nutrients, ammonia and phytoplankton cell number, collected from 15 sampling sites during the stratification period (May-October) along the coast of Rhodes Island, Greece. Some data pre-processing was carried out for these values: (a) exclusion of outliers (Barnett and Lewis, 1987); and (b) log-transform was applied to reduce the range of the values for the phytoplankton cell number parameter.

\subsection{Development of thematic maps using the Kriging interpolation method}

The Kriging interpolation method takes into account the mathematical characteristics of the general structure of the spatial phenomenon studied (Lancaster and Salkauskas, 1986), being an exact interpolator in the sense that the interpolated values will coincide with the values at the data points (Burrough, 1996). The surface to be interpolated is regarded as a regionalized variable that has a certain degree of continuity (Lam, 1983). It is, therefore, assumed that:

1. the expected difference between any two places $\mathbf{x}$ and $\mathbf{x}+\mathbf{h}$ separated by a distance vector $\mathbf{h}$, known as lag, will be zero $E[Z(\mathbf{x})-$ $Z(\mathbf{x}+\mathbf{h})]=0$; and

2. the variance of differences depends only on the distance between sites (h), in a way that $\operatorname{var}[Z(\mathbf{x})-Z(\mathbf{x}+\mathbf{h})]=E\left[\{Z(\mathbf{x})-Z(\mathbf{x}+\mathbf{h})\}^{2}\right]$ $=2 \gamma(\mathbf{h})$

where $\gamma(\mathbf{h})$ is a function known as semi-variance (Burrough, 1996).

When the above assumptions are met, the function that relates $\gamma$ to $\mathbf{h}$ and is given by the expression:

$$
\gamma(\mathbf{h})=\frac{1}{2 n} \cdot \sum_{i=1}^{n}\left\{Z\left(\mathbf{x}_{i}\right)-Z\left(\mathbf{x}_{i}+\mathbf{h}\right)\right\}^{2}
$$


where $n$ is the number of pairs of observations separated by the lag $\mathbf{h}$, is called experimental variogram and contains all the useful information about the spatial variation of the property, summarizing the general form of the variation, its magnitude and spatial scale (Oliver and Webster, 1990). To render the experimental variogram useful in Kriging interpolation method, it must be fitted by a theoretical model. Consequently, a fitted or theoretical variogram is produced. The expression used to predict the value at an unvisited point $\mathbf{x}_{o}$ is the following:

$Z\left(\mathbf{x}_{o}\right)=\sum_{i=1}^{n} \lambda_{i} Z\left(\mathbf{x}_{i}\right)$

where $Z\left(\mathbf{x}_{i}\right)$ are the data values at points $\mathbf{x}_{i}$ and $\lambda_{i}$ the weights needed for local interpolation with $\sum_{i=1}^{n} \lambda_{i}=1$ (Cressie, 1990).

\subsection{Eutrophication scaling}

The interpolated values of each thematic map can be categorized based on already developed nutrient and phytoplankton cell number concentration trophic scales (Ignatiades et al., 1992; Kitsiou and Karydis, 1998), as shown in Table 1. The different trophic levels can therefore be illustrated on the thematic maps.

\subsection{Standardization of the parameters values}

All values are standardized prior to the application of the multiple criteria choice method, according to Sneath and Sokal (1973):

$z_{i j}=\left(x_{i j}-x_{i}\right) / s_{i}$

where $z_{i j}$ is the standardized value for the $x_{i j}$ element, $x_{i}$ the average of the $i$ th row and $s_{i}$ the standard deviation (S.D.) of this row.

Standardization is a necessary procedure to ensure that all natural scales, some of which may include nominal or ordinal data, are converted to a common value scale with interval properties (Pereira and Duckstein, 1993). The comparison, therefore, of variables with different dimensions could be possible.

\subsection{Multiple criteria choice methodology}

The multiple criteria evaluation/choice methods are frequently used in the field of economics and policy analysis (Janssen, 1992). Their principle is the classification (ranking) of alternative choice possibilities on the basis of various criteria (Nijkamp and Voogd, 1986). The ranking of the alternatives is achieved when an impact matrix is

Table 1

Eutrophication scaling based on nutrient (phosphate, nitrate, ammonia) and phytoplankton cell number; oligotrophic, lowermesotrophic, upper-mesotrophic and eutrophic ranges are given

\begin{tabular}{|c|c|c|c|c|c|c|c|c|}
\hline \multicolumn{9}{|c|}{ Eutrophication scaling } \\
\hline $\begin{array}{l}\text { Phosphate } \\
(\mu \text { g-at.P/l) }\end{array}$ & 0 & & 0.07 & & 0.14 & & 0.68 & \\
\hline Nitrate & 0 & & 0.62 & & 0.65 & & 1.19 & \\
\hline ( $\mu$ g-at.N/l) & & $\begin{array}{l}\text { oligotrophic } \\
\text { range }\end{array}$ & & $\begin{array}{l}\text { lower- } \\
\text { mesotrophic } \\
\text { range }\end{array}$ & & $\begin{array}{l}\text { upper- } \\
\text { mesotrophic } \\
\text { range }\end{array}$ & & $\begin{array}{l}\text { eutrophic } \\
\text { range }\end{array}$ \\
\hline $\begin{array}{l}\text { Ammonia } \\
(\mu \text { g-at.N/l) }\end{array}$ & 0 & & 0.55 & & 1.05 & & 2.20 & \\
\hline $\begin{array}{l}\text { Phytoplankton } \\
\text { cell number } \\
\text { (cells/l) }\end{array}$ & 0 & & $6 \times 10^{3}$ & & $1.5 \times 10^{5}$ & & $9.6 \times 10^{5}$ & \\
\hline
\end{tabular}


formed where a set of scores is attached to the criteria providing information for each alternative (Nijkamp and Voogd, 1986). Although a variety of these methods exist, all of them obey the same principle: the pairwise comparison of the scores for all the alternatives and for each criterion (Nijkamp and Voogd, 1986). The impact matrix can have the following form when $i$ alternatives and $j$ criteria are considered:

$\operatorname{Impact~Matrix}=\left|\begin{array}{ccc}b_{11} & \ldots & b_{1 j} \\ b_{i 1} & \ldots & b_{i j}\end{array}\right|$

where $b_{i j}$ is the score of the alternative $i$ according to the criterion $j$. In the case that $b_{1 j}>b_{2 j}$, the alternative $I_{1}$ dominates over the alternative $I_{2}$ as far as the $j$ criterion is concerned; 'the greater the value, the more favored the criterion' (Hartog et al., 1989).

The advantage of the multiple criteria methods is their ability to deal with mixed qualitative and quantitative information (Nijkamp, 1988; Buckley, 1988; Voogd, 1988). In this work, the Regime multiple criteria choice method (Moriki and
Karydis, 1994; Hartog et al., 1989) was applied; a detailed description of this method is already given in a previous publication (Kitsiou and Karydis, 1998); however, it is briefly repeated here.

According to the Regime method, the pairwise comparison of the alternatives for each criterion results in the creation of regimes. The regimes are vectors of + and - signs; a regime is attributed to each alternative after the pairwise comparison with the rest of the alternatives. Alternative $I_{1}$ is preferred to $I_{2}$ if the sign is + (Janssen, 1992). If $k$ is the total number of alternatives and $\lambda$ the total number of criteria, there will be created $k(k-1)$ regimes of $\lambda$ dimension. The resulting matrix $R$ with dimensions $k(k-1)$ $\times \lambda$ is called the Regime Matrix. If all the criteria are of equal importance, they are assigned the same weight and alternative $I_{1}$ dominates over the $I_{2}$ if the total number of + signs is larger than the total number of - signs. Then, given each regime, the probability that alternative $I$ is more important than the other member of the pair is computed. Therefore, $(k-1)$ probabilities are formed for each alternative and the mean of these probabilities is the probability $p_{i}$ that the alternative $I$ 'wins' a random pairwise compar-

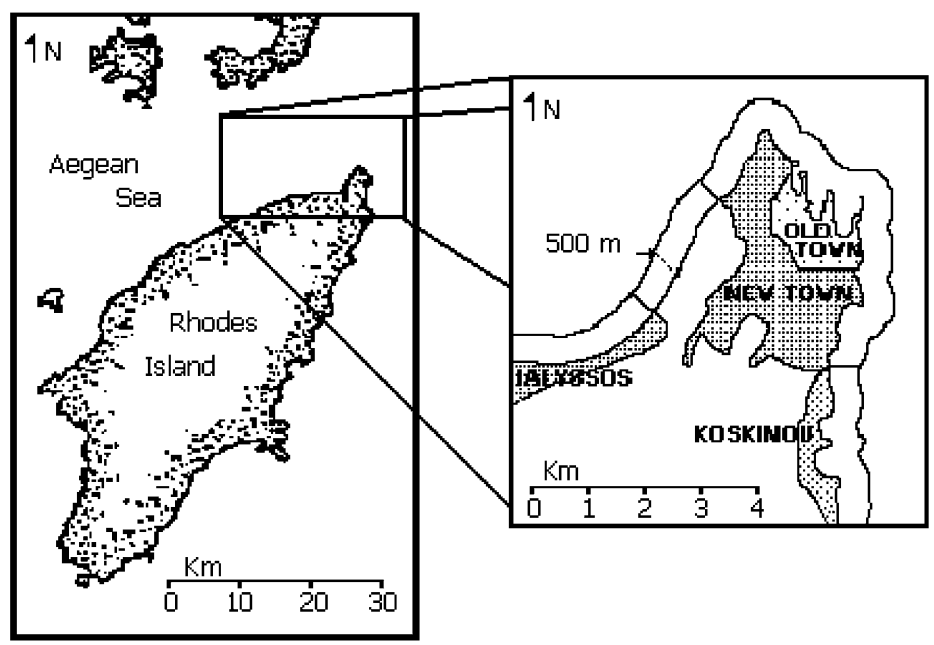

Fig. 1. The study area in the island of Rhodes, Greece where the three sub-areas in the marine environment and the neighboring mainland are shown. 
ison. The ranking according to diminishing values of $p_{i}$ reveals the most important alternative (Janssen, 1992).

\section{Case study: the coastal area of the city of Rhodes}

\subsection{Description of the study area and source of data}

The island of Rhodes, Greece lies in the eastern Mediterranean Sea and covers an area of $1400 \mathrm{~km}^{2}$ (Fig. 1). During the summer, Rhodes city and its surroundings receive more than 1 million visitors; tourism is the main economic activity on the island (Moriki et al., 1995). The study area, shown in Fig. 1, extends to the northeastern part of the island of Rhodes, including also the town of Rhodes (new and old). In the south of Rhodes old town extends an industrial area and along both the north and south coasts of the area of interest many hotels are concentrated. The study area has been divided into three zones: (a) town of Rhodes; (b) Ialyssos; and (c) Koskinou; each one of them also includes the sea area that extends $500 \mathrm{~m}$ away from the coast, as is also illustrated in Fig. 1.

The values of the parameters used for the terrestrial environment of each zone (UNEP, 1993) are given in Table 2. The parameters related to the quality of the marine environment (concentrations of phosphate and nitrate nutri-

Table 2

Parameters used for the terrestrial environment of the study area; SA1: town of Rhodes, SA2: Ialyssos, SA3: Koskinou

\begin{tabular}{|c|c|c|c|c|c|}
\hline \multirow[t]{2}{*}{ Parameters } & \multicolumn{3}{|l|}{ SA1 } & \multirow[t]{2}{*}{ SA2 } & \multirow[t]{2}{*}{ SA3 } \\
\hline & Old town & & New town & & \\
\hline Population & 4605 & & 40895.0 & 7600.0 & 2400.0 \\
\hline Number of shops & & 5352 & & 267.0 & 89.0 \\
\hline Non-cultivated agricultural area (ha) & 0 & & 560.7 & 959.0 & 567.0 \\
\hline Cultivated agricultural area (ha) & 0 & & 220.4 & 697.1 & 667.2 \\
\hline Number of hotel beds & 0 & & 16661.0 & 12894.0 & 3666.0 \\
\hline Sandy beaches $(\mathrm{km})$ & 0 & & 6.1 & 6.7 & 3.0 \\
\hline
\end{tabular}

Table 3

Mean values for the nutrients (phosphate, nitrate, ammonia) and phytoplankton cell number during the stratification period (May-October), in the sampling sites RH1-RH10 and R1-R5

\begin{tabular}{|c|c|c|c|c|}
\hline $\begin{array}{l}\text { Sampling } \\
\text { site }\end{array}$ & $\begin{array}{l}\text { Phosphate } \\
(\mu \text { g-at.P } / 1)\end{array}$ & $\begin{array}{l}\text { Nitrate } \\
(\mu \text { g-at.N/1) }\end{array}$ & $\begin{array}{l}\text { Ammonia } \\
(\mu \text { g-at.N/1) }\end{array}$ & $\begin{array}{l}\text { Phytoplankton cell } \\
\text { number (cells / })\end{array}$ \\
\hline RH1 & 0.13 & 0.84 & 0.84 & 20648 \\
\hline RH2 & 0.08 & 0.47 & 0.63 & 18649 \\
\hline RH3 & 0.07 & 1.76 & 0.48 & 53954 \\
\hline RH4 & 0.07 & 4.37 & 0.69 & 339253 \\
\hline RH5 & 0.07 & 2.45 & 0.67 & 83826 \\
\hline RH6 & 0.10 & 0.57 & 0.51 & 17949 \\
\hline RH7 & 0.08 & 0.38 & 0.56 & 9337 \\
\hline RH8 & 0.11 & 0.34 & 0.75 & 24725 \\
\hline RH9 & 0.09 & 0.27 & 0.79 & 8006 \\
\hline RH10 & 0.07 & 0.30 & 0.65 & 7220 \\
\hline $\mathrm{R} 1$ & 0.02 & 0.19 & 0.43 & 13848 \\
\hline $\mathrm{R} 2$ & 0.02 & 0.21 & 0.30 & 6267 \\
\hline R3 & 0.02 & 0.20 & 0.46 & 2320 \\
\hline $\mathrm{R} 4$ & 0.02 & 0.35 & 0.69 & 4773 \\
\hline R5 & 0.05 & 0.23 & 0.50 & 4533 \\
\hline
\end{tabular}


ents, ammonia and phytoplankton cell number) were selected based on the EUROGOOS Marine Technology Surcey, 1988 (Capobianco, 1999). The datasets came from two research programs that took place during the period 1983-1984 (Karydis et al., 1987, 1988a,b); the 15 sampling sites RH1-RH10 and R1-R5 are given in Figs. 2 and 3 , while the mean values of each parameter for the stratification period (May-October) are shown in Table 3. Detailed description of the sampling methodological procedures has been given in previous work (Karydis and Coccossis, 1990).

\subsection{Application of the methodology: results and discussion}

\subsubsection{Marine environment}

3.2.1.1. Development of thematic maps. Application of the Kriging interpolation method with a spatial resolution of $30 \times 30 \mathrm{~m}$ and categorization of the interpolated values using the eutrophication scal-

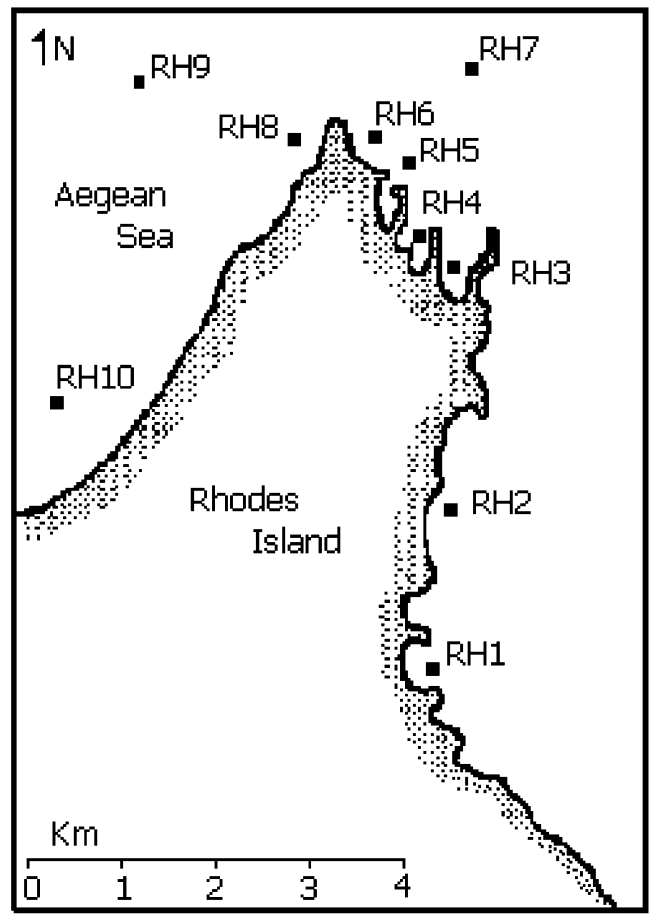

Fig. 2. The sampling sites RH1-RH10 in the marine environment.

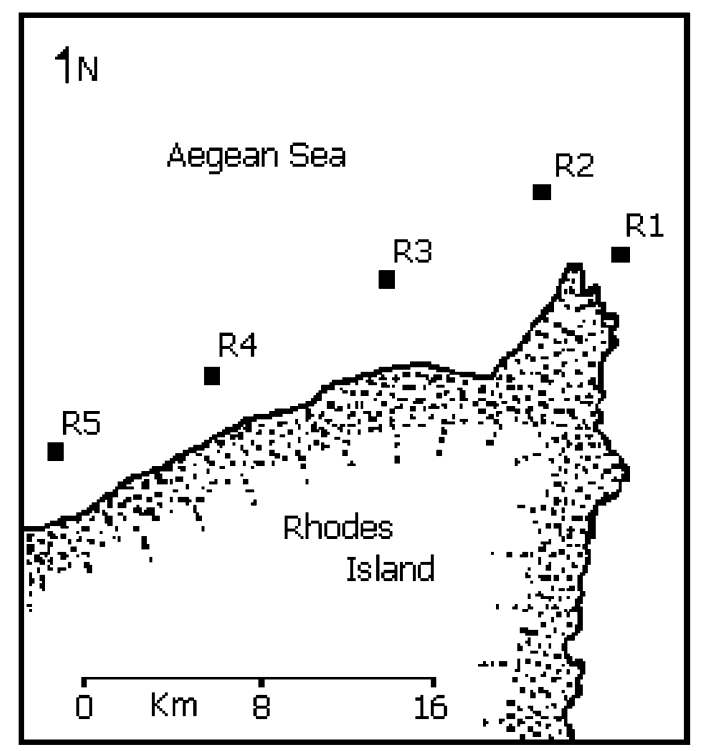

Fig. 3. The sampling sites R1-R5 in the marine environment.

ing of Table 1 resulted in the four thematic maps shown in Fig. 4 where the different trophic levels; eutrophic, upper-mesotrophic, lower-mesotrophic, oligotrophic are clearly illustrated. The spatial distribution of the phosphate nutrients is given in Fig. $4 \mathrm{a}$; the field was characterized as lower mesotrophic along both the coasts of the northwestern part of the town of Rhodes and Koskinou. Upper mesotrophic and eutrophic fields were not indicated, while oligotrophic trends were detected in the marine environment along the west coast of the island. The thematic map of the nitrate nutrients (Fig. 4b) indicated as eutrophic the sea area around the three ports of the town of Rhodes extending far away from the coast and gradually becoming upper-mesotrophic, lower-mesotrophic and finally oligotrophic. The upper-mesotrophic field covered also the Koskinou sea area, while the west coast of the island was again characterized as oligotrophic. In the spatial distribution of ammonia (Fig. 4c), no eutrophic or uppermesotrophic fields were observed. Lowermesotrophic was characterized in the sea environment in the north and northwestern part of the town of Rhodes, in Koskinou and in Ialyssos along the west coast. Finally, the spatial distribution of phytoplankton cell number (Fig. 4d) indi- 


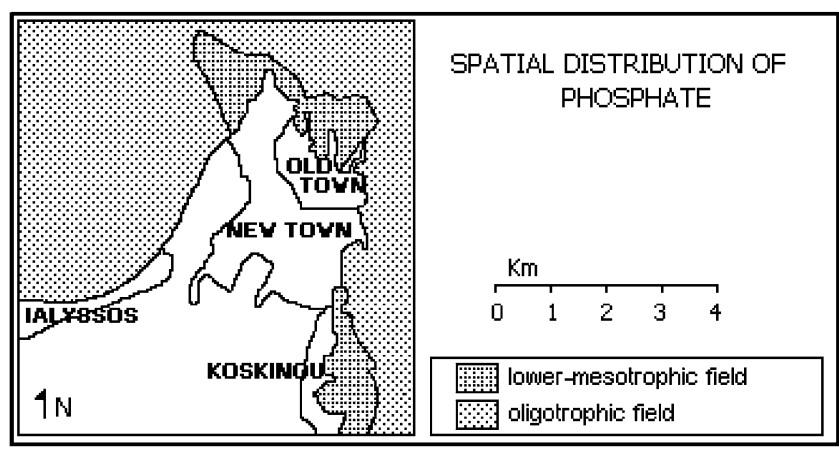

(a)

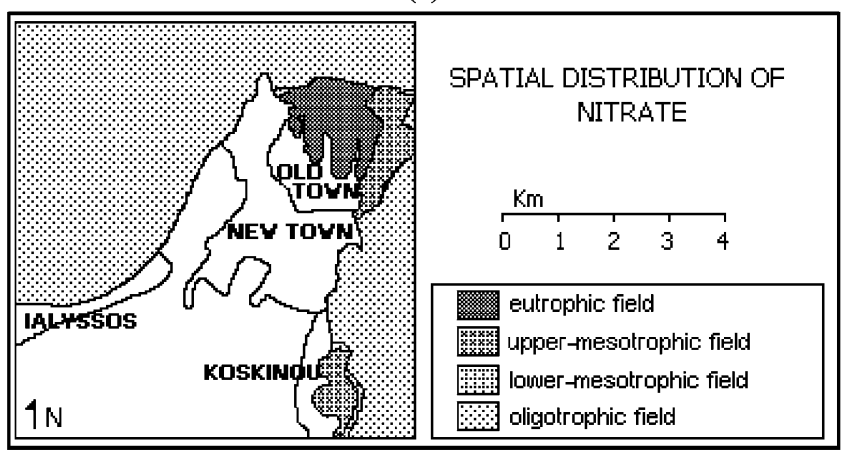

(b)

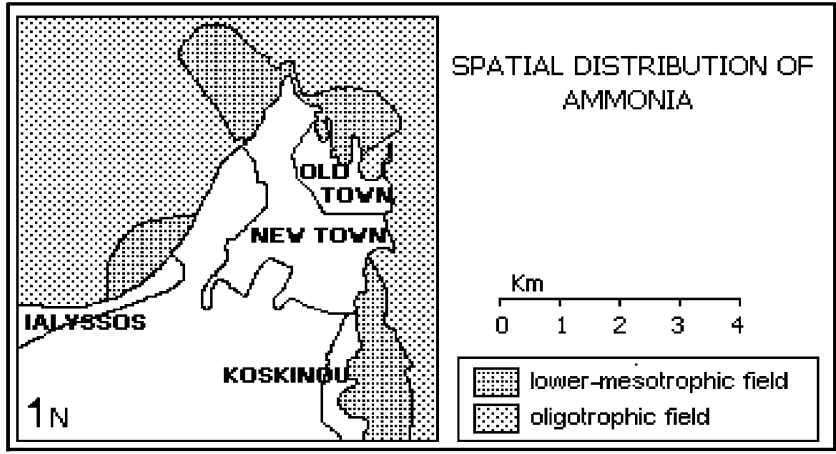

(c)

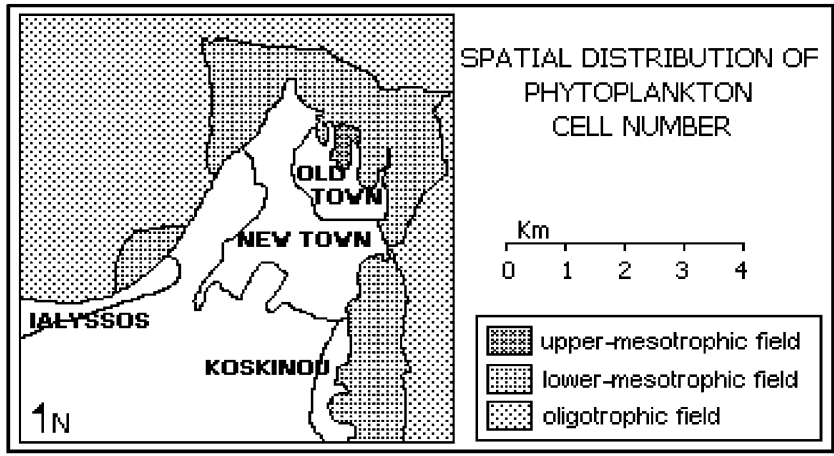

(d)

Fig. 4. Spatial distributions of (a) phosphate, (b) nitrate, (c) ammonia, and (d) phytoplankton cell number. 
Table 4

Means of the interpolated values within the boundaries of each marine sub-area for the nutrients (phosphate, nitrate, ammonia) and phytoplankton cell number; SA1: Town of Rhodes, SA2: Ialyssos, SA3: Koskinou

\begin{tabular}{lrrr}
\hline Parameter & \multicolumn{1}{c}{ SA1 } & \multicolumn{1}{c}{ SA2 } & \multicolumn{2}{c}{ SA3 } \\
\hline Phosphate $(\mu$ g-at.P $/ 1)$ & 0.08 & 0.05 & 0.09 \\
Nitrate $(\mu$ g-at.N/l) & 2.17 & 0.26 & 0.61 \\
Ammonia $(\mu$ g-at.N/1) & 0.59 & 0.54 & 0.69 \\
Phytoplankton cell & 49545.00 & 5358.00 & 13646.00 \\
$\quad$ number (cells $/ 1)$ & & & \\
\hline
\end{tabular}

cated an extended lower-mesotrophic field along the major part of the study area coasts and only a limited upper-mesotrophic field in the port of the town of Rhodes.

\subsubsection{Definition of a zone in the sea $500 \mathrm{~m}$ away} from the coast and calculation of the values that characterize each sub-area. A zone in the sea area that extends $500 \mathrm{~m}$ away from the coast was defined using the appropriate tools of a Geographical Information System (GIS). The mean of the interpolated values within the boundaries of each marine sub-area was calculated for each examined parameter (Table 4); the software
ArcInfo (ArcInfo, version 7.0.2, Environmental Systems Research Institute, Inc.) was used. Each marine sub-area was, therefore, characterized by four values that are given in Table 4 .

\subsubsection{Coastal zone (terrestrial and marine environment)}

3.2.2.1. Creation of the impact matrix of the Regime multiple criteria choice method. The impact matrix of the Regime multiple criteria method was created and it is shown in Table 5a. The three sub-areas represented the alternative choice possibilities as mentioned in Section 2.5, while the values of the 10 parameters formed the criteria. In Table 5a, negative values were given to the criteria $\mathrm{C} 7, \mathrm{C} 8, \mathrm{C} 9$ and $\mathrm{C} 10$ to satisfy the principle of the multiple criteria choice methods 'the greater the value, the more favored the criterion', since high values of these parameters indicate low sea environmental quality. It is noted here that the corresponding values for the phytoplankton cell number are the log-transformed of the initial ones given in Table 4, since the data preprocessing described in Section 2.1 was carried out.

Table 5

The impact matrix for the criteria $\mathrm{C} 1-\mathrm{C} 10$ and the alternatives/sub-areas (SA): (a) without assigning priorities to the criteria and (b) by assigning higher priorities to the criteria related to the marine environmental quality; SA1: town of Rhodes, SA2: Ialyssos, SA3: Koskinou

\begin{tabular}{|c|c|c|c|c|c|c|}
\hline \multirow[t]{2}{*}{ Criteria } & \multicolumn{3}{|c|}{ (a) Without priorities } & \multicolumn{3}{|c|}{ (b) With priorities } \\
\hline & SA1 & SA2 & SA3 & SA1 & SA2 & SA3 \\
\hline C1. Population & 45500.00 & 7600.00 & 2400.00 & -45500.00 & -7600.00 & -2400.00 \\
\hline C2. Number of shops & 5352.00 & 267.00 & 89.00 & -5352.00 & -267.00 & -89.00 \\
\hline $\begin{array}{l}\text { C3. Non-cultivated agricultural } \\
\text { area (ha) }\end{array}$ & 560.70 & 959.00 & 567.00 & 560.70 & 959.00 & 567.00 \\
\hline $\begin{array}{l}\text { C4. Cultivated agricultural area } \\
\text { (ha) }\end{array}$ & 220.40 & 697.10 & 667.20 & -220.40 & -697.10 & -667.20 \\
\hline C5. Number of hotel beds & 16661.00 & 12894.00 & 3666.00 & -16661.00 & -12894.00 & -3666.00 \\
\hline C6. Sandy beaches $(\mathrm{km})$ & 6.10 & 6.70 & 3.00 & -6.10 & -6.70 & -3.00 \\
\hline $\begin{array}{l}\text { C7. Concentration of phosphate } \\
(\mu \text { g-at.P } / 1)\end{array}$ & -0.08 & -0.05 & -0.09 & -0.08 & -0.05 & -0.09 \\
\hline $\begin{array}{l}\text { C8. Concentration of nitrate } \\
(\mu \text { g-at.N/l) }\end{array}$ & -2.17 & -0.26 & -0.61 & -2.17 & -0.26 & -0.61 \\
\hline $\begin{array}{l}\text { C9. Concentration of ammonia } \\
(\mu \text { g-at.N/1) }\end{array}$ & -0.59 & -0.54 & -0.69 & -0.59 & -0.54 & -0.69 \\
\hline $\begin{array}{l}\text { C10. Concentration of } \\
\text { phytoplankton (cells / } 1)\end{array}$ & -4.70 & -3.73 & -4.14 & -4.70 & -3.73 & -4.14 \\
\hline
\end{tabular}




\subsubsection{Standardization of the impact matrix and} application of the Regime multiple criteria choice method. The standardization procedure described in Section 2.4 was applied and a new impact matrix was created (Table 6a). The Regime method was then applied twice. The first time, no priorities were assigned to the criteria; they were all, therefore, considered of equal importance; the resulted ranking of the three sub-areas is given in Table 7a. According to this ranking, the Ialyssos sub-area was the most favorable from a development point of view, considering that socio-economic and environmental parameters were of equal importance, while Koskinou was placed last. Koskinou represented, therefore, the less developed zone of the study area. During the second application of the regime method, higher priority was given to the criteria related to the marine environmental quality. The priority order for the criteria was the following: $\mathrm{C} 10, \mathrm{C} 8, \mathrm{C} 7$, C9, C5, C1, C4, C3, C2, C6. Criterion C10 (phytoplankton cell number) is the most representative parameter characterizing marine eutrophication (Colombo et al., 1992); nitrate nutrients (C8) represent a significant limiting factor in the phytoplankton's growth, while phosphate nutrients (C7) and ammonia (C9) are also important indicators of the eutrophication trends of the sea environment (Valiela, 1995). The criterion C5 (number of hotel beds) has a high significance for the system examined (Lanquar, 1995), since it reflects the number of tourists in the area. Tourists and local inhabitants (criterion C1) are a major source of environmental pollution in coastal communities (Madan and Rawat, 2000). The extent of agricultural areas can be very significant for the quality of the marine environment, since agriculture is considered as an important cause of the supply of nutrients to the sea coastal zone (Capobianco, 1999). However, the impact of cultivated agricultural areas (criterion C4) is much more significant, since pest management is often undertaken by using pesticides that act as persistent organic pollutants (POPs); POPs accumulate in the groundwater and may influence the coastal areas as non-point pollution (Capobianco, 1999). In that case, a negative sign was also given to the criteria $\mathrm{C} 1, \mathrm{C} 2, \mathrm{C} 4, \mathrm{C} 5$ and $\mathrm{C} 6$, because the high values of these parameters represent a negative impact on the marine environment. The impact matrix is given in Table 5b, the standardized impact matrix in Table $6 \mathrm{~b}$ and the resulted ranking of the three

Table 6

The standardized impact matrix for the criteria $\mathrm{C} 1-\mathrm{C} 10$ and the alternatives/sub-areas (SA): (a) without assigning priorities to the criteria and (b) by assigning higher priorities to the criteria related to the marine environmental quality; SA1: town of Rhodes, SA2: Ialyssos, SA3: Koskinou

\begin{tabular}{|c|c|c|c|c|c|c|}
\hline \multirow[t]{2}{*}{ Criteria } & \multicolumn{3}{|c|}{ (a) Without priorities } & \multicolumn{3}{|c|}{ (b) With priorities } \\
\hline & SA1 & SA2 & SA3 & SA1 & SA2 & SA3 \\
\hline C1. Population & 1.15 & -0.46 & -0.68 & -1.15 & 0.46 & 0.68 \\
\hline C2. Number of shops & 1.15 & -0.55 & -0.61 & -1.15 & 0.55 & 0.61 \\
\hline $\begin{array}{l}\text { C3. Non-cultivated agricultural } \\
\text { area (ha) }\end{array}$ & -0.59 & 1.15 & -0.56 & -0.59 & 1.15 & -0.56 \\
\hline $\begin{array}{l}\text { C4. Cultivated agricultural area } \\
\text { (ha) }\end{array}$ & -1.15 & 0.63 & 0.52 & 1.15 & -0.63 & -0.52 \\
\hline C5. Number of hotel beds & 0.84 & 0.27 & -1.11 & -0.84 & -0.27 & 1.11 \\
\hline C6. Sandy beaches $(\mathrm{km})$ & 0.42 & 0.72 & -1.10 & -0.42 & -0.72 & 1.10 \\
\hline $\begin{array}{l}\text { C7. Concentration of phosphate } \\
(\mu \mathrm{g}-\text { at.P } / 1)\end{array}$ & -0.50 & 1.00 & -1.00 & -0.50 & 1.00 & -1.00 \\
\hline $\begin{array}{l}\text { C8. Concentration of nitrate } \\
(\mu \mathrm{g}-\text { at.N/l) }\end{array}$ & -1.14 & 0.74 & 0.39 & -1.14 & 0.74 & 0.39 \\
\hline $\begin{array}{l}\text { C9. Concentration of ammonia } \\
(\mu \mathrm{g}-\text { at.N } / \mathrm{l})\end{array}$ & 0.25 & 0.88 & -1.00 & 0.25 & 0.88 & -1.00 \\
\hline $\begin{array}{l}\text { C10. Concentration of } \\
\text { Phytoplankton (cells /1) }\end{array}$ & -1.04 & 0.94 & 0.10 & -1.14 & 0.94 & 0.10 \\
\hline
\end{tabular}


sub-areas in Table 7b. This time, Koskinou was placed first representing the zone with the best marine environmental quality, Ialyssos second and the town of Rhodes last. The results of Table 7 indicated that Ialyssos and the town of Rhodes gained in order when criteria were of equal importance, since most of services and tourist activities are situated in these sub-areas, but lost in ecological value.

\subsubsection{Evaluation and robustness of the method-} ology. Synthesis of the criteria $\mathrm{C} 1-\mathrm{C} 10$ was applied twice for evaluating the sensitivity of the proposed methodology.

(a) First synthesis of the criteria set

The value of population (C1) was added to the number of hotel beds (C5) for creating a criterion representative of the total number of population (permanent citizens and tourists). Similarly, the value of the criterion C3 (non-cultivated agricultural area) was added to that of the criterion $\mathrm{C} 4$ (cultivated agricultural area) to create a new one representative of the total extent of the agricultural area. The synthesis of the criteria related to the marine environment was made as described in the following steps: (a) The means of the interpolated values within the boundaries of each marine sub-area for each parameter (Table 4) were assigned to a certain trophic level (eutrophic, upper-mesotrophic, lower-mesotrophic, oligotrophic) based on the eutrophication scale of Table 1. (b) An ordinal value was assigned to each trophic level (1): to the eutrophic; (2): to the upper-mesotrophic; (3): to the lower-mesotrophic; and (4): to the oligotrophic (Table 8). For example, the mean value of the interpolated values for the phosphate in sub-area 1 was 0.08 , which corresponded to the lower-mesotrophic trophic level. A value of 3 was, therefore, assigned to this sub-area regarding the phosphate parameter, as shown in Table 8. (c) Co-estimation of the information incorporated in each parameter was achieved by addition of the ordinal values of Table 8 for each sub-area: sub-area 1 corre-

Table 7

Results of the Regime multiple criteria choice method (a) without assigning priorities to the criteria $\mathrm{C} 1-\mathrm{C} 10$ and (b) by assigning higher priorities to the criteria related to the marine environmental quality

\begin{tabular}{|c|c|c|c|c|}
\hline \multirow[t]{2}{*}{ Ranking } & \multicolumn{2}{|c|}{ (a) Without priorities } & \multicolumn{2}{|l|}{ (b) With priorities } \\
\hline & Sub-area & Result & Sub-area & Result \\
\hline 1 & Ialyssos & 1.000 & Koskinou & 1.000 \\
\hline 2 & Town of Rhodes & 0.333 & Ialyssos & 0.500 \\
\hline 3 & Koskinou & 0.167 & Town of Rhodes & 0.000 \\
\hline
\end{tabular}

Table 8

Characterization of the trophic level of each sub-area for each parameter and final characterization of each sub-area after co-estimation of all the parameters; 1: eutrophic, 2: upper-mesotrophic, 3: lower-mesotrophic, 4: oligotrophic field

\begin{tabular}{|c|c|c|c|}
\hline Parameter & $\begin{array}{l}\text { Town of Rhodes } \\
\text { (SA1) }\end{array}$ & $\begin{array}{l}\text { Ialyssos } \\
\text { (SA2) }\end{array}$ & $\begin{array}{l}\text { Koskinou } \\
\text { (SA3) }\end{array}$ \\
\hline Phosphate ( $\mu$ g-at.P /1) & 3 & 4 & 3 \\
\hline Nitrate $(\mu$ g-at.N/1) & 1 & 4 & 4 \\
\hline Ammonia ( $\mu$ g-at.N/l) & 4 & 4 & 3 \\
\hline $\begin{array}{l}\text { Phytoplankton cell number } \\
\text { (cells/1) }\end{array}$ & 3 & 4 & 3 \\
\hline SUM & 11 & 16 & 13 \\
\hline $\begin{array}{l}\text { Quality of the marine } \\
\text { environment }\end{array}$ & $\begin{array}{l}3 \\
\text { (lower-mesotrophic) }\end{array}$ & $\begin{array}{l}4 \\
\text { (oligotrophic) }\end{array}$ & $\begin{array}{l}3 \\
\text { (lower-mesotrophic) }\end{array}$ \\
\hline
\end{tabular}


Table 9

Eutrophication scale for the characterization of the trophic level of a sub-area when four parameters are considered simultaneously; 1: eutrophic, 2: upper-mesotrophic, 3: lower-mesotrophic, 4: oligotrophic field

Eutrophication scale

\begin{tabular}{|c|c|c|c|c|c|c|c|c|}
\hline 1 & & 1 & & 2 & & 3 & & 4 \\
\hline 1 & eutrophic & 1 & upper-mesotrophic & 2 & lower-mesotrophic & 3 & oligotrophic & 4 \\
\hline 1 & field & 1 & field & 2 & field & 3 & field & 4 \\
\hline 1 & & 2 & & 3 & & 4 & & 4 \\
\hline 4 & & 5 & & 9 & & 13 & & 16 \\
\hline
\end{tabular}

sponded to a sum of 11 ; sub-area 2 to a sum of 16; and sub-area 3 to a sum of 13. (d) A new trophic scale based on the ordinal values characterizing each trophic level (1: eutrophic; 2: upper-mesotrophic; 3: lower-mesotrophic; and 4: oligotrophic) was developed considering the coestimation of four parameters. The boundary values of each trophic field were calculated based on

Table 10

The impact matrix as formed after the synthesis of the criteria of Table 5 (a) without assigning priorities to the criteria and (b) by assigning higher priorities to the criteria related to the marine environmental quality; SA 1: town of Rhodes, SA2: Ialyssos, SA3: Koskinou

\begin{tabular}{|c|c|c|c|c|c|c|}
\hline \multirow[t]{2}{*}{ Criteria } & \multicolumn{3}{|c|}{ (a) Without priorities } & \multicolumn{3}{|c|}{ (b) With priorities } \\
\hline & SA1 & SA2 & SA3 & SA1 & SA2 & SA3 \\
\hline $\begin{array}{l}\text { C1a. Population and number } \\
\text { of hotel beds }\end{array}$ & 62161.0 & 20494.0 & 6066.0 & -62161.0 & -20494.0 & -6066.0 \\
\hline C2a. Number of shops & 5352.0 & 267.0 & 89.0 & -5352.0 & -267.0 & -89.0 \\
\hline $\begin{array}{l}\text { C3a. Non-cultivated and } \\
\text { cultivated agricultural area } \\
\text { (ha) }\end{array}$ & 781.1 & 1656.1 & 1234.2 & -781.1 & -1656.1 & -1234.2 \\
\hline C4a. Sandy beaches $(\mathrm{km})$ & 6.1 & 6.7 & 3.0 & -6.1 & -6.7 & -3.0 \\
\hline $\begin{array}{l}\text { C5a. Quality of the marine } \\
\text { environment }\end{array}$ & 3.0 & 4.0 & 3.0 & 3.0 & 4.0 & 3.0 \\
\hline
\end{tabular}

Table 11

The standardized impact matrix for the criteria $\mathrm{C} 1 \mathrm{a}-\mathrm{C} 5 \mathrm{a}$ and the alternatives/sub-areas (SA): (a) without assigning priorities to the criteria and (b) by assigning higher priorities to the criteria related to the marine environmental quality; SA1: town of Rhodes, SA2: Ialyssos, SA3: Koskinou

\begin{tabular}{|c|c|c|c|c|c|c|}
\hline \multirow[t]{2}{*}{ Criteria } & \multicolumn{3}{|c|}{ (a) Without priorities } & \multicolumn{3}{|c|}{ (b) With priorities } \\
\hline & SA1 & SA2 & SA3 & SA1 & SA2 & SA3 \\
\hline $\begin{array}{l}\text { C1a. Population and number of } \\
\text { hotel beds }\end{array}$ & 1.12 & -0.31 & -0.81 & -1.12 & 0.31 & 0.81 \\
\hline C2a. Number of shops & 1.15 & -0.55 & -0.61 & -1.15 & 0.55 & 0.61 \\
\hline $\begin{array}{l}\text { C3a. Non-cultivated and cultivated } \\
\text { agricultural area } \\
\text { (ha) }\end{array}$ & -1.01 & 0.99 & 0.02 & 1.01 & -0.99 & -0.02 \\
\hline C4a. Sandy beaches $(\mathrm{km})$ & 0.42 & 0.72 & -1.10 & -0.42 & -0.72 & 1.10 \\
\hline $\begin{array}{l}\text { C5a. Quality of the marine } \\
\text { environment }\end{array}$ & -0.57 & 1.16 & -0.57 & -0.57 & 1.16 & -0.57 \\
\hline
\end{tabular}


Table 12

Results of the Regime multiple criteria choice method (a) without assigning priorities to the criteria C1a-C5a and (b) by assigning higher priorities to the criteria related to the marine environmental quality

\begin{tabular}{|c|c|c|c|c|}
\hline \multirow[t]{2}{*}{ Ranking } & \multicolumn{2}{|c|}{ (a) Without priorities } & \multicolumn{2}{|l|}{ (b) With priorities } \\
\hline & Sub-area & Result & Sub-area & Result \\
\hline 1 & Ialyssos & 1.000 & Koskinou & 1.000 \\
\hline 2 & Town of Rhodes & 0.500 & Ialyssos & 0.500 \\
\hline 3 & Koskinou & 0.000 & Town of Rhodes & 0.000 \\
\hline
\end{tabular}

the following principle: the trophic trend assigned to a sub-area will be the one that characterizes the majority of the examined parameters. Consequently, as shown in Table 9, values between 4 and 5 represent an eutrophic field, 6-9 an uppermesotrophic field, 10-13 a lower-mesotrophic field and 14-16 an oligotrophic field. (e) The trophic field of each sub-area was finally characterized based on the sum values of Table 8 and the trophic scale of Table 9. As a result, the marine environment of the sub-areas 1 and 3 was representative of lower-mesotrophic conditions and sub-area 2 of oligotrophic ones (Table 8).

The new impact matrix is shown in Table 10a and the standardized one in Table 11a. The regime method was again applied twice. The first time, all

Table 13

The impact matrix as formed after the synthesis of the criteria of Table 10, (a) without assigning priorities to the criteria and (b) by assigning higher priorities to the criteria related to the marine environmental quality; SA1: Town of Rhodes, SA2: Ialyssos, SA3: Koskinou

\begin{tabular}{|c|c|c|c|c|c|c|}
\hline \multirow[t]{2}{*}{ Criteria } & \multicolumn{3}{|c|}{ (a) Without priorities } & \multicolumn{3}{|c|}{ (b) With priorities } \\
\hline & SA1 & SA2 & SA3 & SA1 & SA2 & SA3 \\
\hline $\begin{array}{l}\text { C1b. (Population and number } \\
\text { of hotel beds)/sandy beaches }\end{array}$ & 10190.3 & 3058.8 & 2022.0 & -10190.3 & -3058.8 & -2022.0 \\
\hline C2b. Number of shops & 5352.0 & 267.0 & 89.0 & -5352.0 & -267.0 & -89.0 \\
\hline $\begin{array}{l}\text { C3b. (Non-cultivated and } \\
\text { cultivated agricultural area)/ } \\
\text { sandy beaches }(\mathrm{ha} / \mathrm{km})\end{array}$ & 128.0 & 247.2 & 411.4 & -128.0 & -247.2 & -411.4 \\
\hline $\begin{array}{l}\text { C4b. Quality of the marine } \\
\text { environment }\end{array}$ & 3.0 & 4.0 & 3.0 & 3.0 & 4.0 & 3.0 \\
\hline
\end{tabular}

Table 14

The standardized impact matrix for the criteria $\mathrm{C} 1 \mathrm{~b}-\mathrm{C} 4 \mathrm{~b}$ and the alternatives/sub-areas (SA): (a) without assigning priorities to the criteria and (b) by assigning higher priorities to the criteria related to the marine environmental quality; SA1: town of Rhodes, SA2: Ialyssos, SA3: Koskinou

\begin{tabular}{|c|c|c|c|c|c|c|}
\hline \multirow[t]{2}{*}{ Criteria } & \multicolumn{3}{|c|}{ (a) Without priorities } & \multicolumn{3}{|c|}{ (b) With priorities } \\
\hline & SA1 & SA2 & SA3 & SA1 & SA2 & SA3 \\
\hline $\begin{array}{l}\text { C1b. (Population and number } \\
\text { of hotel beds)/sandy beaches }\end{array}$ & 1.15 & -0.46 & -0.69 & -1.15 & 0.46 & 0.69 \\
\hline $\mathrm{C} 2 \mathrm{~b}$. Number of shops & 1.15 & -0.55 & -0.61 & -1.15 & 0.55 & 0.61 \\
\hline $\begin{array}{l}\text { C3b. (Non-cultivated and } \\
\text { cultivated agricultural area)/ } \\
\text { sandy beaches }(\mathrm{ha} / \mathrm{km})\end{array}$ & -0.94 & -0.11 & 1.05 & 0.94 & 0.11 & -1.05 \\
\hline $\begin{array}{l}\text { C4b. Quality of the marine } \\
\text { environment }\end{array}$ & -0.57 & 1.16 & -0.57 & -0.57 & 1.16 & -0.57 \\
\hline
\end{tabular}


the criteria were considered of equal importance and the final ranking is given in Table 12a, while the second one priority was given to the criteria related to the quality of the marine environment. The priority order for the criteria was the following: C5a, C1a, C3a, C2a, C4a; that time, a negative sign was given to the criteria $\mathrm{C} 1 \mathrm{a}, \mathrm{C} 3 \mathrm{a}$, $\mathrm{C} 2 \mathrm{a}, \mathrm{C} 4 \mathrm{a}$, while the values of the criterion $\mathrm{C} 5 \mathrm{a}$ remained intact, since its high values represent good marine environmental quality. The impact matrix for this case is given in Table $10 \mathrm{~b}$ and the standardized one in Table 11b. The resulted ranking is shown in Table $12 \mathrm{~b}$. It was observed that the synthesis of the criteria did not affect the ranking of the three zones in both cases compared to the results illustrated in Table 7 .

(b) Second synthesis of the criteria set

The criteria where further synthesized as following: both criteria $\mathrm{C} 1 \mathrm{a}$ and $\mathrm{C} 3 \mathrm{a}$ of Table 10 were divided by the value of the criterion $\mathrm{C} 4 \mathrm{a}$ (sandy beaches in $\mathrm{km}$ ) for estimating the intensity of the activity (Table 13a). The same procedure concerning the application of the Regime method, without assigning priorities to the criteria, was followed. The standardized impact matrix and the resulted ranking are shown in Table 14a and Table $15 \mathrm{a}$, respectively.

In the second run, the priority order for the criteria was the following: $\mathrm{C} 4 \mathrm{~b}, \mathrm{C} 1 \mathrm{~b}, \mathrm{C} 3 \mathrm{~b}, \mathrm{C} 2 \mathrm{~b}$, while a negative sign was given to the criteria C1b, C3b, C2b (Table 13b). The standardized impact matrix is the one of Table $14 \mathrm{~b}$, while the ranking is given in Table 15b. It was observed once again no difference in the ranking of the three zones for both cases compared to the results illustrated in Tables 7 and 12 .

\section{Conclusions}

The need for a systematic, coherent and active intervention towards the sustainable development of the coastal areas has been widely recognized (Sorensen and McCreary, 1990). However, the tools developed for that purpose are, most of the time, applied in a rather fragmented and conflicting way, providing a quite insufficient means for the integrated coastal zone management; a need for a synthetic application of existing tools is, therefore, highly demanded (O'Regan, 1996). An efficient operation of a coastal management mechanism should involve the selection of the appropriate criteria for assessing the environmental, social and economic impacts. Furthermore, since coastal management occurs in a complex dynamic spatial system, if a tool is to respond, it must be characterized by flexibility to quickly review and revise the new information acquired, to be able to enrich the criteria and the guidelines and to evaluate properly the impacts of a proposed project in the coastal resources and ecosystems. Finally, the ranking of coastal zones can be proven to be very useful to coastal managers, since it is a mean for comparing different areas and evaluating their potential for development.

The aim of the present study was to propose a methodology for the multi-dimensional evaluation and ranking of coastal areas. More precisely, the purpose was to examine the effectiveness of the combination of GIS and multiple criteria choice methods as integrated tools in coastal management. The island of Rhodes in Greece was selected as a case study, since it represents a

Table 15

Results of the Regime multiple criteria choice method (a) without assigning priorities to the criteria C1b-C4b and (b) by assigning higher priorities to the criteria related to the marine environmental quality

\begin{tabular}{|c|c|c|c|c|}
\hline \multirow[t]{2}{*}{ Ranking } & \multicolumn{2}{|c|}{ (a) Without priorities } & \multicolumn{2}{|l|}{ (b) With priorities } \\
\hline & Sub-area & Result & Sub-area & Result \\
\hline 1 & Ialyssos & 0.650 & Koskinou & 1.000 \\
\hline 2 & Town of Rhodes & 0.560 & Ialyssos & 0.500 \\
\hline 3 & Koskinou & 0.290 & Town of Rhodes & 0.000 \\
\hline
\end{tabular}


typical example of excessive concentration of various conflicting activities in a small area.

Within the frame of a GIS a variety of analytical, statistical and modeling tools can be applied to transform data and make them suitable for a given application (EPA, 1999). In coastal zone management studies, GIS provide a receptacle for scattered data from diverse sources and an improvement of the visualization of such data (Capobianco, 1999). Regarding the multiple criteria choice methods, they have already been used for assessing the quality of the marine environment (Moriki and Karydis, 1994) as well as for decision making (Hartog et al., 1989) and coastal management (Moriki et al., 1995), since they have a number of advantages: (a) they are distribution-free, which means that they do not depend on parametric procedures and do not require any assumptions of the data. (b) The significance of certain variables can be adjusted by the assignment of priorities. (c) Integration of any type of information can be handled.

In the proposed methodology, the following steps were involved: (a) data manipulation may be required as a preliminary step such as omission of outliers and/or data transformation to restrict the range of the values. (b) Division of the study area into zones/sub-areas, including part of the terrestrial and the marine coastal environment within the frame of a GIS. (c) Interpolation of the data collected from the marine environment to produce continuous spatial surfaces for each examined parameter; at this stage, the Kriging interpolation method was used with a spatial resolution of $30 \times 30 \mathrm{~m}$. (d) Use of an appropriate eutrophication scale based on nutrient concentrations and phytoplankton cell number for the categorization of the interpolated data. (e) Generation of thematic maps for each examined parameter. (f) Calculation of the mean of the interpolated values within the boundaries of each zone in the marine environment for every parameter. (g) Creation of the impact matrix using the parameters related both to the terrestrial and marine environment. (h) Standardization of the values of the impact matrix. (i) Application of the regime multiple criteria choice method using the sub-areas as alternative choice possibilities and the parameters values as criteria. (j) Consideration of equal importance for all the criteria during the first run of the regime method, while higher priority for the criteria related to the marine environmental quality during the second run. (k) Ranking of the sub-areas. (l) Appropriate synthesis of the criteria set and reapplication of the regime method.

The developed methodology seems useful in simultaneously analyzing spatial information from various sources, revealing the current state of each coastal zone and exploring its potential for future development according to various aspects. Moreover, the assignment of priorities to the criteria allows the reflectance of different viewpoints to be examined explicitly. The methodology is flexible in possible alterations; for example, if it is considered necessary, the extent of the sub-areas could easily be transformed in the terrestrial as well as in the marine environment using GIS. The methodology could, therefore, be characterized as a dynamic tool, since new or revised information could be easily inserted into the system (new values of certain criteria or even new criteria) and the priorities assigned to the criteria could be easily revised allowing the detection of long term or short term changes following specific events. Another important aspect is the simplicity in application and the clear illustration of the results. That point is quite interesting since, in general, the gap between technology developers and possible users is quite wide, especially when mathematical models are used that are shared by small groups of specialists. In the described methodology, the ranking of the zones provides an explicit view of the status of the coastal zone without involving any complexity in the analysis. Furthermore, the use of different configurations of the criteria set did not affect the ranking of the sub-areas, proving the stability and robustness of the methodology. A disadvantage could be considered the difficulty to define the priorities of the criteria, since the development of a consensus seems quite difficult. However, use of the proposed methodology with a careful focus on the needs and characteristics of the study area might provide a quite useful guidance for ex- 
ploring its dynamic and predicting future trends or developing scenarios for future planning.

\section{References}

Ballinger RC, Smith HD. The management of the coastal zone of Europe. Ocean Coast Manage 1994;22:45-85.

Barnett V, Lewis T. Outliers in statistical data, 2nd edition. Chitsester: John Wiley and Sons, 1987.

Barras J, Johnston J, Johnson C. Using GIS and image processing technology to asset wetland planning, protection and restoration in coastal Louisiana. GIS/LIS Proceedings, 25-27 October 1994, Phoenix, Arizona, 1994:44-52.

Belfiore S. Recent developments in coastal management in the European Union. Ocean Coast Manage 2000;43: 123-135.

Buckley M. Multicriteria evaluation: measures, manipulation and meaning. Environ Plann B: Plann Des 1988;15:55-64.

Burrough PA. Principles of geographical information systems for land resources assessment. Oxford: Clarendon Press, 1996.

Camhis M, Coccossis H. Coastal planning and management perspectives. Ekistics 1982;49(293):92-97.

Capobianco M. EU Demonstration Programme on Integrated Management in Coastal Zones 1997-1999: Role and use of technologies in relation to ICZM. Final report, Tecnomare S.p.A., Venezia, 1999.

Carlson SA, Fox L, Garrett RL. Virtual GIS and ecosystem assessment in the Klamath Province, California-Oregon. GIS/LIS Proceedings, 25-27 October 1994, Phoenix, Arizona, 1994:133-141.

Carver SJ. Integrating multi-criteria evaluation into geographic information systems. Int J Geogr Info Sys 1991; 5(3):321-339.

Clark JR. Coastal ecosystem management (a technical manual for the conservation of coastal zone resources). New York: John Wiley and Sons, 1983, p. 928.

Coccossis H. Tourism and sustainability: perspectives and implications in sustainable tourism? In: Priestley G, Edwards $\mathrm{A}$, Coccossis $\mathrm{H}$, editors. London $\mathrm{CAB}$ International, 1996:1-21.

Colombo G, Ferrari I, Ceccherelli VU, Rossi R, editors. Marine eutrophication and population dynamics. Fredensborg: Olsen \& Olsen, 1992.

Cressie N. The origins of Kriging. Math Geol 1990; 22(3):239-252.

Doody JP, Pamplin CF, Gilbert C, Bridge L. Information required for integrated coastal zone management. European Commission 1999. Available from fttp://europa.eu.int/comm/dg11/iczm/themanal.htm.

(EC) European Commission Seminar 'Towards a European Union strategy for integrated coastal zone management'. Brussels, July 2nd, 1999.

(EPA) Environmental Protection Agency. Geographic Information Systems Tools. Available from http://www. epa.gov/epahome/gis.htm, 1999.
Golojuch C. Designing an interface for a coastal water quality prediction system. Urban and Regional Information Systems Association (URISA) Proceedings, 7-11 August 1994, Milwaukee, Wisconsin, 1994:582-587.

Goodchild M, Haining R, Wise S et al. Integrating GIS and spatial data analysis: problems and possibilities. Int $\mathrm{J}$ Geogr Info Sys 1992;6(5):407-423.

Gray JS. Eutrophication in the sea. In: Colombo G, Ferrari I, Ceccherelli VU, Rossi R, editors. Marine eutrophication and population dynamics. Fredensborg: Olsen \& Olsen, 1992:3-16.

Hartog JA, Hinloopen E, Nijkamp P. A sensitivity analysis of multicriteria choice-methods. An application on the basis of the optimal site selection for a nuclear power plant. Energy Econ, October 1989; 293-300.

Ignatiades L, Karydis M, Vounatsou P. A possible method for evaluating oligotrophy and eutrophication based on nutrient concentration scales. Mar Pollut Bull 1992;24:238-243.

Janssen R. Multiobjective decision support for environmental management. Amsterdam: Kluwer, 1992, p. 232.

Jones AR. GIS in coastal management: a progress review. In: Furness R, editor. CoastGIS 95, Proceedings of the International Symposium on GIS and Computer Mapping for Coastal Zone Management, Cork, Ireland, 3-5 February, 1995, University of College Cork, Cork, Ireland, 1995: 165-178.

Karydis M, Georgopoulos D, Ignatiades L, Nikolaidou A, Papathanasiou E, Siokou-Fragou J. Oceanographic and ecological survey of the SE Aegean Sea (1983-1984). Data Report, National Centre for Marine Research, Greece, 1987.

Karydis M, Georgopoulos D, Ignatiades L, Nikolaidou A, Papathanasiou E, Siokou-Fragou J. Ecological and oceanographic survey of the sea area of Rhodes. Technical report. National Centre for Marine Research, Hydrobiological Station of Rhodes, 1988a.

Karydis M, Arvanitidis A, Economides D, Ignatiades L. Monitoring the quality of the coastal waters of Rhodes: The marine ecosystem. Technical report. National Center for Marine Research (NCMR), Greece, 1988b.

Karydis M, Coccossis H. Use of multiple criteria for eutrophication assessment of coastal waters. Environ Monit Assess 1990;14:89-100.

Kenchington RA. Decision making for marine environments. Mar Pollut Bull 1992;24(2):69-76.

King G. Participation in the ICZM processes: mechanisms and procedures needed-final report. European Commission, 1999. Available from http://europa.eu.int/ comm/dg11/iczm/themanal.htm.

Kitsiou D, Karydis M. Development of categorical mapping for quantitative assessment of eutrophication. J Coast Conserv 1998;4:35-44.

Lam NSN. Spatial interpolation methods: a review. Am Cartogr 1983;10(2):129-149.

Lancaster P, Salkauskas K. Curve and surface fitting. London: Academic Press, 1986. 
Lanquar R. Tourisme et Environment en Mediterranee: enjeux et prospective. Les fascicules du Plan Bleu 8, Economica, France, 1995.

Madan S, Rawat L. The impacts of tourism on the environment of Mussoorie, Garhwal Himalaya, India. Environmentalist 2000;20(3):253-259.

Moriki A, Karydis M. Application of multicriteria choice methods in assessing eutrophication. Environ Monit Assess 1994;33:1-18.

Moriki A, Coccossis H, Karydis M. Multicriteria evaluation in coastal management. J Coastal Res 1995;12:171-178.

Nijkamp P. Culture and region: a multidimensional evaluation of monuments. Environ Plann B: Plann Des 1988;15:5-14.

Nijkamp P, Voogd H. A survey of qualitative multiple criteria choice models. In: Nijkamp P, Leitner H, Wringley N, editors. Measuring the unmeasurable. Dordrtecht: Kluwer Nijhoff, 1986:425-447.

Oliver MA, Webster R. Kriging: a method of interpolation for geographical information systems. Int J Geogr Info Sys 1990;4(3):313-332.

O'Regan PR. The use of contemporary information technologies for coastal research and management - a review. J Coast Res 1996;12(1):192-204.

Pereira JMC, Duckstein L. Int J Geogr Info Sys 1993;7(5):407-424.

Sneath PHA, Sokal RR. Numerical taxonomy. San Francisco, USA: Freeman and Co, 1973, p. 573.
Sorensen J, McCreary S. Institutional arrangements for managing coastal resources and environments. DC: US Nat. Parks Service, Int. Affairs Office, 1990.

Tivy J, O'Hare G. Human impact on the ecosystem. Edinburgh and New York: Oliver \& Biyd, 1981.

Tsakiri-Strati M, Arvanitis A, Maniatis I, Papadopoulou M. Monitoring, management and protection of Amvrakikos Gulf using remote sensing data in a GIS environment. Proceedings of the EGIS/MARI Fifth European Conference and Exhibition on Geographical Information Systems, 1994:514-523.

UNEP/MAP/Blue Plan CAMP (Coastal Area Management Programme) Rhodes. Development-environment scenarios for Rhodes. Mytilene: University of the Aegean, 1993.

UNESCO. Coasts: environment and development briefs, 1993.

Valiela I. Marine ecological processes, 2nd edition. New York: Springer-Verlag, 1995, p. 686.

Vollenweider RA. Coastal marine eutrophication: principles and control. In: Vollenweider RA, Marchetti R, Viviani R, editors. Marine coastal eutrophication. London: Elsevier, 1992:1-20.

Voogd H. Multicriteria evaluation for urban and regional planning. London: Pion, 1983.

Voogd H. Multicriteria evaluation: measures, manipulation and meaning - a reply. Environ Plann B: Plann Des 1988;15:65-72. 